\title{
KEMAMPUAN EKSTRAK KULIT KAYU DUA SPESIES MACARANGA DALAM MENGHAMBAT PERTUMBUHAN BAKTERI ENTEROCOCCUS FAECALIS
}

\section{THE ABILITY OF TWO SPECIES OF MACARANGA WOOD BARK EXTRACTS TO INHIBIT THE GROWTH OF BACTERIA ENTEROCOCCUS FAECALIS}

\author{
Beri Hidayat ${ }^{1) \star}$, Fathul Yusro ${ }^{2)}$, Yeni Mariani ${ }^{3)}$ \\ 1,2,3Fakultas Kehutanan Universitas Tanjungpura Jalan Imam Bonjol Pontianak 78124 \\ *Email: beri66000@gmail.com
}

\begin{abstract}
Infection in the oral cavity, especially in the teeth root canals are often faced by Indonesian people, and one of the causes was bacterium Enterococcus faecalis. The potential plants as an antibacterial are two species of Macaranga, namely Merkubung (Macaranga gigantea) and Mangpurang (Macaranga triloba). This study aimed to analyze the presence of secondary metabolites content of those two bark extracts and their ability to inhibit the growth of $E$. faecalis. The research methods carried out were powder prepared, moisture content measurement, extracts yield determination, phytochemical assays, and antibacterial assay. The yield of ethanol extracts of M. gigantea bark was 9.18\% (moisture content 9.15\%), and M. triloba was 9.70\% (moisture content 8.56\%). These two extracts positively contain phenolic, tannin, saponin, terpenoids, flavonoids, and alkaloids. The concentration level of $100 \mathrm{mg} / \mathrm{mL}$ is the best concentration of two extracts to inhibit the growth of $E$. faecalis, and the M. gigantea is the best extract in inhibiting the growth of E. faecalis.
\end{abstract}

Keywords: Phytochemical screening, antibacterial activity, Macaranga gigantea, Macaranga triloba, Enterococcus faecalis

\begin{abstract}
ABSTRAK
Infeksi pada rongga mulut terutama di saluran akar gigi sering dialami oleh orang Indonesia dan salah satu penyebabnya adalah bakteri Enterococcus faecalis. Tanaman yang potensial sebagai antibakteri adalah dua species Macaranga yaitu merkubung (Macaranga gigantea) dan mangpurang (Macaranga triloba). Penelitian ini bertujuan untuk menganalisis kandungan metabolit sekunder ekstrak kulit kayu dari dua species Macaranga dan kemampuannya dalam menghambat pertumbuhan bakteri $E$. faecalis. Metode penelitian yang dilakukan adalah pembuatan serbuk, pengukuran kadar air serbuk, penghitungan rendemen ekstrak, uji fitokimia dan pengujian aktivitas antibakteri $E$. faecalis. Rendemen ekstrak etanol kulit kayu $M$. gigantea adalah 9,18\% (KA 9,15\%) dan M. triloba sebesar 9,70\% (KA 8,56\%). Ekstrak positif mengandung fenolik, tanin, saponin, terpenoid, flavonoid dan alkaloid. Level konsentrasi $100 \mathrm{mg} / \mathrm{mL}$ merupakan konsentrasi terbaik dari kedua jenis ekstrak untuk menghambat pertumbuhan bakteri $E$. faecalis, namun diantara kedua jenis ekstrak tersebut yang terbaik dalam menghambat pertumbuhan E. faecalis adalah M. gigantea.
\end{abstract}

Kata kunci: Fitokimia, antibakteri, Macaranga gigantea, Macaranga triloba, Enterococcus faecalis 


\section{PENDAHULUAN}

Kondisi masyarakat yang sejahtera merupakan salah satu tujuan pembangunan nasional. Salah satu kesejahteraan masyarakat menurut United Nations Development Program (UNDP) adalah kesejahteraan di bidang kesehatan (Sulaeman et al., 2012). Pemerintah Indonesia menuangkan faktor kesejahteraan masyarakat dalam bidang kesehatan ini sebagai salah satu dimensi dalam Indeks Desa Membangun (IDM) (Hamidi et al., 2015). Kemandirian masyarakat di bidang kesehatan dapat diwujudkan dengan memanfaatkan potensi sumberdaya alam dan pengetahuan lokal masyarakat terkait tumbuhan obat untuk mengobati penyakit yang sering dialami oleh masyarakat. Salah satu tumbuhan obat yang dimanfaatkan oleh masyarakat untuk mengobati penyakit adalah dari genus Macaranga.

Genus Macaranga memiliki banyak spesies; dua diantaranya adalah $M$. gigantea dan $M$. triloba. Masyarakat di Kalimantan Barat khususnya di Kabupaten Kapuas Hulu mengenal $M$. gigantea dengan nama merkubung, sedangkan $M$. triloba dengan nama mangpurang. Kedua spesies ini digunakan oleh masyarakat secara tradisional sebagai obat untuk mengatasi sariawan dengan bagian yang digunakan adalah getahnya. Menurut Apriani et al., (2014) ekstrak daun $M$. gigantea efektif dalam menghambat pertumbuhan bakteri E. coli. Amirta et al. (2017) menyatakan bahwa masyarakat Sabah dan Serawak memanfaatkan daun $M$. gigantea sebagai anti infeksi bakteri dan $M$. triloba sebagai obat diare. Berdasarkan hal tersebut maka dua spesies tersebut sangat memungkinkan sebagai agen antibakteri.
Banyak penyakit yang disebabkan oleh bakteri. Salah satunya adalah infeksi pada saluran akar gigi yang utamanya disebabkan oleh bakteri Enterococcus faecalis. Menurut Ramadhinta et al., (2016), bakteri yang paling sering ditemukan menyerang rongga mulut (20 dari 30 kasus) khususnya dalam proses perawatan saluran akar adalah bakteri gram positif $E$. faecalis. Senada dengan itu, Pasril dan Yuliasanti (2014) juga mengemukakan bahwa bakteri $E$. faecalis memiliki peran mencapai 80\%-90\% dalam menyebabkan infeksi saluran akar. Berdasarkan hal tersebut, perlu adanya penanganan penyakit yang disebabkan oleh infeksi bakteri $E$. faecalis.

Penggunaan obat sintetis dalam mengobati infeksi pada saluran akar sudah sangat umum di kalangan masyarakat. Namun, obat sintetis mulai dikhawatirkan efek samping yang akan muncul jika mengonsumsi secara terusmenerus. Banyak masyarakat yang memilih untuk kembali menggunakan obat tradisional dengan alasan seperti mempunyai tingkat resiko yang jauh lebih rendah dibandingkan obat sintesis jika digunakan secara tepat, mudah ditemukan, ketersediaannya yang cukup melimpah dan harganya yang relatif lebih terjangkau (Wasito, 2011; Wila et al., 2018). Obat tradisional dari tanaman $M$. gigantea dan $M$. triloba khususnya dari ekstrak kulit kayu sangat potensial, namun belum ada pengujian aktivitas antibakteri pada bagian kulit batang dari genus Macaranga khususnya merkubung ( $M$. gigantea) dan mangpurang ( $M$. triloba) terhadap $E$. faecalis. 
Penelitian ini bertujuan untuk menganalisis kandungan metabolit sekunder ekstrak kulit kayu dari dua species Macaranga dan kemampuannya dalam menghambat pertumbuhan bakteri $E$. faecalis.

\section{METODE PENELITIAN}

Penelitian dilaksanakan di beberapa tempat antara lain Wood Workshop dan Lab. Teknologi Kayu Kayu (Fakultas Kehutanan), Lab. Kimia (Fakultas MIPA) Universitas Tanjungpura dan Unit Lab. Kesehatan Provinsi Kalimantan Barat dengan waktu pelaksanaan penelitian selama \pm 3 bulan yang dimulai dari penyiapan bahan hingga pengolahan data.

Beberapa alat dan bahan yang digunakan antara lain hammer mill, mesh screen, timbangan analitik, desikator, botol reagen, shaker, erlenmeyer, kertas saring meteran, aluminium foil waterbath, gelas ukur, batang pengaduk, pisau stainless, kuas, jarum ose, autoclave, laminar air flow, oven, incubator, cawan petri, mikroskop binokuler digital, mikropipet, kertas cakram whatman No 4. Pinset, hot plate, cotton swab steril, pipet tetes, pipet ukur, vortex dan botol vial. Bahan yang digunakan adalah kulit batang merkubung ( $M$. gigantea) dan mangpurang ( $M$. triloba) yang diambil dari salah satu kebun warga desa yang berada di Kabupaten Kapuas Hulu Kalimantan Barat, bakteri $E$. faecalis ATCC 29212, etanol 96\%, metanol, $\mathrm{BaCl}_{2} 1,175 \%$, dietil eter, $\mathrm{H}_{2} \mathrm{SO}_{4}, \quad \mathrm{H}_{2} \mathrm{SO}_{4} \quad 1 \%$, larutan Liebermann-Buchard, $\mathrm{NaOH} 10 \%$, $\mathrm{FeCl}_{3} 1 \%$, serbuk Magnesium, larutan buffer $(\mathrm{NaCl}), \mathrm{HCL}$ pekat, pereaksi Meyer, MHA (Mueller Hinton Agar) Dragendorff, Wagner, aquades, dan antibiotik tetracycline $30 \mu \mathrm{g} / \mathrm{mL}$.

\section{Persiapan sampel}

Langkah awal dimulai dengan pengambilan kulit batang $M$. gigantea atau $M$. triloba dengan cara menguliti bagian kulit batang pada posisi tinggi $\pm 50 \mathrm{~cm}$ dari permukaan tanah menggunakan pisau. Bagian yang diambil adalah kulit bagian dalam dan tidak melukai bagian kambium. Selanjutnya, kulit batang dibersihkan menggunakan kuas untuk membersihkan kotoran yang menempel pada kulit batang. Setelah itu, kulit batang dipotong dalam ukuran kecil \pm 2 $\mathrm{cm}$ yang dilanjutkan proses pengeringan dengan cara dijemur sampai kering. Kulit batang yang sudah kering digiling menggunakan hammer mill guna mendapatkan serbuk yang nantinya akan diayak menggunakan saringan berukuran lolos 40 mesh tertahan 60 mesh.

\section{Pengukuran Kadar Air}

Dua alumunium foil yang sudah diketahui beratnya, masing-masing dimasukkan serbuk kulit batang $M$. gigantea (2 g) atau M. triloba (2 g) dan dilakukan pengovenan (suhu $103 \pm 2^{\circ} \mathrm{C}$; 24 jam). Setelah itu, sampel dikeluarkan dari dalam oven dan dimasukkan kedalam desikator dan dibiarkan selama 15 menit, dan ditimbang kembali sampel tersebut. Perlakuan tersebut dilakukan berulang sampai diperoleh berat serbuk yang konstan. Persentase kadar air dihitung berdasarkan persamaan (Manuhuwa, 2007) yang tertera di bawah ini:

$K A=\frac{B A-B K O}{\text { BKO }} \times 100 \%$

Dimana:

KA adalah kadar air

BA adalah berat/bobot serbuk mulamula $(\mathrm{g})$

BKO adalah berat/bobot serbuk akhir (g) 
Pengukuran rendemen ekstrak

Pelarut etanol $96 \%$ sebanyak 20

$\mathrm{mL}$ dimasukkan kedalam erlenmeyer yang sudah berisi $1 \mathrm{~g}$ serbuk kulit batang $M$. gigantea atau $M$. triloba, di shaker selama 24 jam dan ekstrak yang diperoleh dipisahkan dari serbuk menggunakan kertas saring. Perlakuan tersebut diulang hingga tidak ada lagi ekstrak yang terlarut dalam pelarut etanol. Ekstrak cair yang dihasilkan selanjutnya dimasukkan ke wadah (cawan porselin) yang beratnya sudah diketahui, diletakkan diatas waterbath (suhu $55^{\circ} \mathrm{C}$ ) selama 24 jam agar pelarut yang digunakan teruap, dan dilakukan pengovenan selama 15 menit pada suhu $60^{\circ} \mathrm{C}$ untuk menguapkan pelarut yang tersisa pada cawan porselin. Kemudian dilakukan penstabilan suhu dengan dimasukkan kedalam desikator. Setelah itu, ditimbang dan dihitung rendemennya menggunakan persamaan (Rahmah et al., 2014).

Rendemen ekstrak $(\mathrm{RE})=\frac{\mathrm{a}}{(1-\mathrm{x}) \mathrm{t}} \times 100 \%$

Dimana:

a adalah berat/bobot ekstrak ( $\mathrm{g}$ )

$\mathrm{b}$ adalah berat/bobot serbuk ( $\mathrm{g}$ )

$\mathrm{x}$ adalah kadar air (\%)

Penyiapan ekstrak untuk sampel pengujian

Pelarut etanol 96\% sebanyak $1000 \mathrm{~mL}$ dimasukkan kedalam botol reagen yang sudah berisi $200 \mathrm{~g}$ serbuk kulit batang $M$. gigantea atau $M$. triloba, dishaker selama 24 jam agar homogen dan ekstrak yang diperoleh dipisahkan dari serbuk menggunakan kertas saring. Perlakuan tersebut diulangi sebanyak 4 kali sampai diperoleh filtrat agak bening. Filtrat yang dihasilkan dimasukkan kedalam cawan kaca, selanjutnya dioven dengan suhu 40$55^{\circ} \mathrm{C}$ hingga didapatkan ekstrak kental, dan selanjutnya di waterbath pada suhu $60^{\circ} \mathrm{C}$ hingga didapatkan ekstrak kristal.

\section{Skrining Fitokimia}

Pelarut metanol sebanyak $10 \mathrm{~mL}$ dituangkan pada wadah (tabung reaksi) yang didalamnya telah terdapat $1 \mathrm{~g}$ ekstrak etanol kulit batang $M$. gigantea atau M. triloba (Mailuhu et al., 2017). Selanjutnya, dilakukan uji skrining fitokimia mengikuti prosedur Harbone (1996) yang telah mengalami sedikit perubahan/modifikasi.

\section{Alkaloid}

Pereaksi $\mathrm{H}_{2} \mathrm{SO}_{4} 2 \mathrm{~N}$ sebanyak 10 tetes dituangkan pada 3 wadah (tabung reaksi) yang didalamnya telah terdapat $1 \mathrm{~mL}$ ekstrak kulit batang $M$. gigantea atau M. triloba. Adanya alkaloid pada ekstrak akan terdeteksi jika pada wadah pertama ditambahkan pereaksi Dragendorff dan terbentuk endapan warna merah jingga. Pada wadah kedua akan terbentuk endapan berwarna coklat jika ditambahkan pereaksi Wagner, serta endapan berwarna putih jika ditambahkan pereaksi Meyer.

\section{Flavonoid}

a. Uji flavonoid menggunakan logam magnesium dan $\mathrm{HCl}$ pekat

Serbuk magnesium (Mg) dan 2 tetes $\mathrm{HCl}$ pekat dituangkan pada wadah (tabung reaksi) yang didalamnya telah terdapat $1 \mathrm{~mL}$ ekstrak kulit batang $M$. gigantea atau $M$. triloba. Pengocokan dengan kuat dilakukan pada tabung reaksi tersebut dan jika terjadi perubahan warna pada larutan uji menjadi jingga dengan disertakan adanya buih dalam intensitas yang banyak, hal tersebut membuktikan adanya flavonoid.

b. Uji flavonoid menggunakan $\mathrm{H}_{2} \mathrm{SO}_{4}$ Pereaksi $\mathrm{H}_{2} \mathrm{SO}_{4} \quad 2 \mathrm{~N}$ sebanyak 2 tetes dituangkan pada wadah 
(tabung reaksi) yang didalamnya telah terdapat $1 \mathrm{~mL}$ ekstrak kulit batang $M$. gigantea atau $M$. triloba. Pengocokan dengan kuat dilakukan pada tabung reaksi tersebut dan akan terdeteksi adanya flavonoid apabila mengalami perubahan warna menjadi coklat, kuning atau merah; hal tersebut membuktikan adanya flavonoid.

\section{Terpenoid dan steroid}

Pereaksi asam sulfat $\left(\mathrm{H}_{2} \mathrm{SO}_{4}\right)$ dan asam asetat anhidrat $\left(\mathrm{CH}_{3} \mathrm{CO}\right)_{2} \mathrm{O}$ masing-masing sebanyak 1 tetes serta 2 tetes dietil eter diteteskan pada bagian plat tetes yang sudah berisi larutan kering ekstrak kulit batang $M$. gigantea atau $M$. triloba. Kemudian, penetesan dilakukan di setiap titik, dimana terdapat tiga titik dalam pengujian ini. Kontrol pada titik pertama, uji terpenoid pada titik kedua dan pengujian steroid pada titik ketiga diplat tetes. Apabila terdapat perubahan warna pada larutan uji menjadi coklat, biru, merah atau ungu, membuktikan terdeteksinya terpenoid. Untuk senyawa steroid warna larutan berubah menjadi biru atau hijau.

\section{Fenolik}

Pereaksi besi (III) klorida $\left(\mathrm{FeCl}_{3}\right) 1 \%$ sebanyak 2-3 tetes dituangkan pada wadah (tabung reaksi) yang didalamnya telah terdapat $1 \mathrm{~mL}$ larutan ekstrak kulit batang $M$. gigantea atau $M$. triloba. Senyawa fenolik terdeteksi apabila larutan berubah warna menjadi biru kehitaman.

\section{Tanin}

Perekasi $\mathrm{FeCl}_{3}$ 1\% sebanyak 10 tetes dituangkan pada wadah (tabung reaksi) yang didalamnya telah terdapat $1 \mathrm{~mL}$ ekstrak kulit batang $M$. gigantea atau $M$. triloba. Apabila terdapat perubahan warna pada larutan uji menjadi hijau kehitaman, hal tersebut membuktikan adanya tannin.

\section{Saponin}

Air panas sebanyak $5 \mathrm{~mL}$ dituangkan pada wadah (tabung reaksi) yang didalamnya telah terdapat $1 \mathrm{~mL}$ ekstrak kulit batang $M$. gigantea atau M. triloba. Pengocokan dengan kuat dilakukan pada tabung reaksi tersebut dan selanjutnya ditambahkan larutan $\mathrm{HCl} 2 \mathrm{~N}$ sebanyak 2 tetes. Apabila terdapat buih pada larutan uji dalam jumlah yang banyak dan bertahan dalam waktu yang relatif lama (10 menit), hal tersebut membuktikan terdeteksinya saponin.

\section{Pembuatan media MHA (Mueller-} Hinton Agar)

Aquadest sebanyak $1000 \mathrm{~mL}$ dituangkan pada wadah (erlenmeyer) yang didalamnya telah terdapat serbuk MHA (38 g). Kemudian diletakkan diatas penangas untuk proses pemanasan, dan peng-homogenan menggunakan bantuan magnetic stirrer. Selanjutnya dilakukan pensterilisasian media menggunakan autoclave (suhu $121^{\circ} \mathrm{C}$ ) yang bertekanan 1 atmosfer dengan waktu selama 15 menit.

Pembuatan larutan Mc. Farland 1 Larutan $\mathrm{BaCl}_{2}$ 1,175\% sebanyak 0,1 $\mathrm{mL}$ dituangkan pada wadah (erlenmeyer) yang didalamnya telah terdapat asam sulfat $1 \%$ sebanyak 9,9 $\mathrm{mL}$. Kemudian dilakukan pengocokan hingga terbentuk dan terlihat menjadi keruh. Standar kekeruhan larutan yang dibuat harus setara dengan standar Mc. Farland 1 dengan konsentrasi bakteri $300 \times 10^{6} \mathrm{CFU} / \mathrm{mL}$ (Dasopang, 2017).

\section{Pembuatan biakan}

Larutan MHA steril dituangkan pada wadah (cawan petri) sebanyak $6 \mathrm{~mL}$, kemudian didiamkan beberapa menit 
sehingga memadat. Selanjutnya, pembuatan suspensi menggunakan isolat bakteri yang diambil dengan alat (jarum ose) steril, kemudian dituangkan pada wadah (tabung reaksi) yang didalamnya telah terdapat larutan buffer sebanyak $3 \mathrm{~mL}$. Kemudian, dilakukan pengocokan hingga homogen dan setarakan kekeruhannya dengan larutan Mc. Farland 1 yang telah dibuat. Langkah berikutnya dilakukan pen-swab-an suspensi bakteri pada media MHA menggunakan Cotton Swab steril.

\section{Uji daya hambat pertumbuhan} antibakteri

Kertas cakram berdiameter $6 \mathrm{~mm}$ ditetaskan dengan larutan ekstrak etanol kulit batang $M$. gigantea atau $M$. triloba menggunakan mikropipet sebanyak $20 \mu \mathrm{L}$. Kemudian didiamkan beberapa menit hingga larutan menyerap secara merata pada kertas cakram. Selanjutnya, proses peletakan kertas cakram menggunakan penjepit steril pada permukaan media MHA yang telah tersuspensi oleh bakteri uji. Proses inkubasi selama 24 jam pada cawan petri yang berisi biakan tersebut menggunakan inkubator dengan suhu $35^{\circ} \mathrm{C}$.

Aktivitas antimikroba diukur sebagai diameter hambatan yang terbentuk setelah ekstrak berdifusi. Pengukuran daya hambat pertumbuhan bakteri menggunakan mistar dalam satuan $\mathrm{mm}$. Data hasil pengukuran diameter zona hambat pada bakteri uji dijabarkan secara statistik dengan Rancangan Acak Lengkap (RAL) Faktorial (Gaspersz, 2006). Selanjutnya analisis data dilakukan menggunakan SPSS 24. Nilai hambatan pertumbuhan bakteri selanjutnya dibandingkan dengan kategori penghambatan pertumbuhan bakteri (Tabel 1).

\section{HASIL DAN PEMBAHASAN}

Rendemen Ekstrak Etanol Kulit Batang M. gigantea dan M. triloba

Hasil ekstraksi pada penelitian ini (Gambar 1) memperoleh rendemen ekstrak etanol kulit batang merkubung (M. gigantea) sebesar 9,18\% (kadar air serbuk 9,15\%) dan mangpurang (M. triloba) sebesar 9,70\% (kadar air serbuk 8,56\%). Rendemen ini tergolong lebih tinggi jika dibandingkan dengan rendemen ekstrak kulit kayu tanaman lain seperti jengkol, nangka dan raru yang memperoleh hasil rendemen ekstrak sebesar 5,41\%, $7,11 \%$ dan $8,41 \%$ (Trina et al., 2014). Selain itu, pada penelitian Yusro et al. (2016) yang menggunakan ekstrak kulit batang dari 11 jenis tanaman, 8 diantaranya menghasilkan ekstrak di bawah 9,05\%. Jika dibandingkan dengan bagian daun pada tanaman lain, kedua jenis ekstrak masih tergolong tinggi, dimana dari lima jenis tanaman yang berbeda (penahan, tekeriho, bungur, tebelion dan kerokak) rendemen ekstrak yang dihasilkan berkisar antara 4,33\%8,99\% (Mariani et al., 2016).

Tabel 1. Kategori Penghambatan Pertumbuhan Bakteri

\begin{tabular}{cc}
\hline Diameter zona bening $(\mathbf{m m})$ & $\begin{array}{c}\text { Kategori penghambatan pertumbuhan } \\
\text { bakteri }\end{array}$ \\
\hline$\geq 20$ & Sangat Kuat \\
$11-19$ & Kuat \\
$5-10$ & Sedang \\
$<5$ & Lemah \\
\hline
\end{tabular}

(Sumber: Anita et al., 2014) 


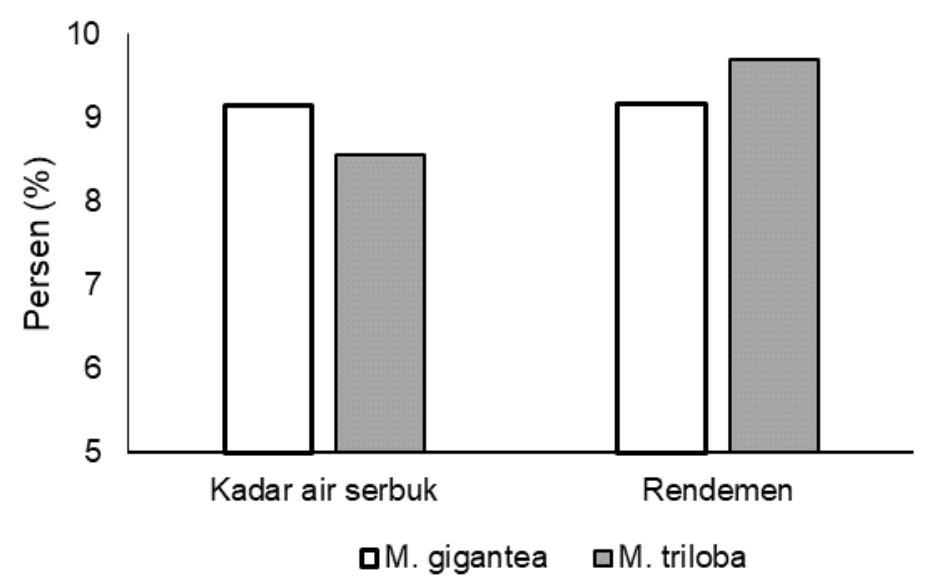

Gambar 1. Kadar air serbuk dan rendemen ekstrak etanol kulit batang M. gigantea dan M. triloba

Tingginya nilai yang dihasilkan oleh rendemen ekstrak pada penelitian ini diduga dipengaruhi oleh jenis pelarut etanol yang digunakan. Menurut Aziz et al., (2009), pelarut etanol merupakan jenis pelarut yang memiliki tingkat polaritas tinggi dan titik didih yang rendah. Selain itu, etanol juga merupakan pelarut yang efektif dalam menghambat pertumbuhan mikroorganisme pada sampel uji, bersifat netral, tidak beracun, dan absorbsinya baik. Bahkan menurut Widyastuti (2010) dan Trina et al., (2014), penggunaan etanol sebagai pelarut dalam bidang kesehatan khususnya obat-obatan menunjukkan hasil yang aman dikarenakan sesuai dengan lisensi Badan POM.

Bagian tanaman yang digunakan dalam proses ekstraksi juga diduga mempengaruhi besarnya nilai rendemen yang dihasilkan. Menurut Sjostrom (1981) pada umumnya dari segi kuantitas kulit batang lebih kaya akan kandungan zat ekstraktifnya, dimana saat dalam keadaan kering pada kulit batang, terdapat konstituen lipofil dan hidrofil yang tingkat kandungan total dari keduanya mencapai 20-40\% dibandingkan bagian lain pada tanaman.

\section{Skrining Fitokimia}

Penentuan adanya golongan senyawa metabolit sekunder yang terdapat pada suatu ekstrak dapat dilakukan dengan cara skrining fitokimia (Astarina et al., 2013). Hasil pengujian menunjukkan bahwa ekstrak etanol kulit batang $M$. gigantea dan $M$. triloba mengandung beberapa golongan senyawa metabolit sekunder yang tertera pada Tabel 2 .

\section{Uji Aktivitas Antibakteri Terhadap E. faecalis}

Pengujian yang dilakukan pada penelitian ini menggunakan metode difusi (disc diffusion Kirby and Baur) dengan kertas cakram Whatman bernomor 41 untuk melihat respon hambatan aktivitas antibakteri ( $E$. faecalis). Selain itu, pengujian juga menggunakan kontrol positif (tetracycline) dan kontrol negatif (etanol 96\%) yang bertujuan untuk memastikan zona bening yang terdapat di sekeliling kertas cakram murni hasil dari senyawa-senyawa metabolit sekunder yang terkandung pada kedua jenis ekstrak. Level konsentrasi ekstrak yang digunakan pada penelitian ini yaitu, masingmasing sama 4 level konsentrasi (50, 100,150 dan $200 \mathrm{mg} / \mathrm{mL}$ ) baik pada M. gigantea ataupun M. triloba. 
Tabel 2. Hasil uji fitokimia ekstrak etanol M. gigantea dan M. triloba

\begin{tabular}{lcc|}
\hline \multicolumn{1}{c}{ Parameter Uji } & Merkubung (M. gigantea) & Mangpurang (M. triloba) \\
\hline Alkaloid (Dragendroff) & +++ & +++ \\
Alkaloid (Wagner) & - & + \\
Alkaloid (Meyer) & - & - \\
Flavonoid (Mg+HCl) & + & +++ \\
Flavonoid $\left(\mathrm{H}_{2} \mathrm{SO}_{4} 2 \mathrm{~N}\right)$ & - & + \\
Flavonoid $(\mathrm{NaOH} 10 \%)$ & +++ & ++ \\
Saponin & + & ++ \\
Terpenoid & ++ & + \\
Steroid & - & - \\
Tanin & +++ & +++ \\
Fenolik & +++ & +++ \\
\hline
\end{tabular}

Keterangan :

$(-)=$ Tidak ada $(+)=$ Sedikit $\quad(++)=$ Sedang $\quad(+++)=$ Banyak

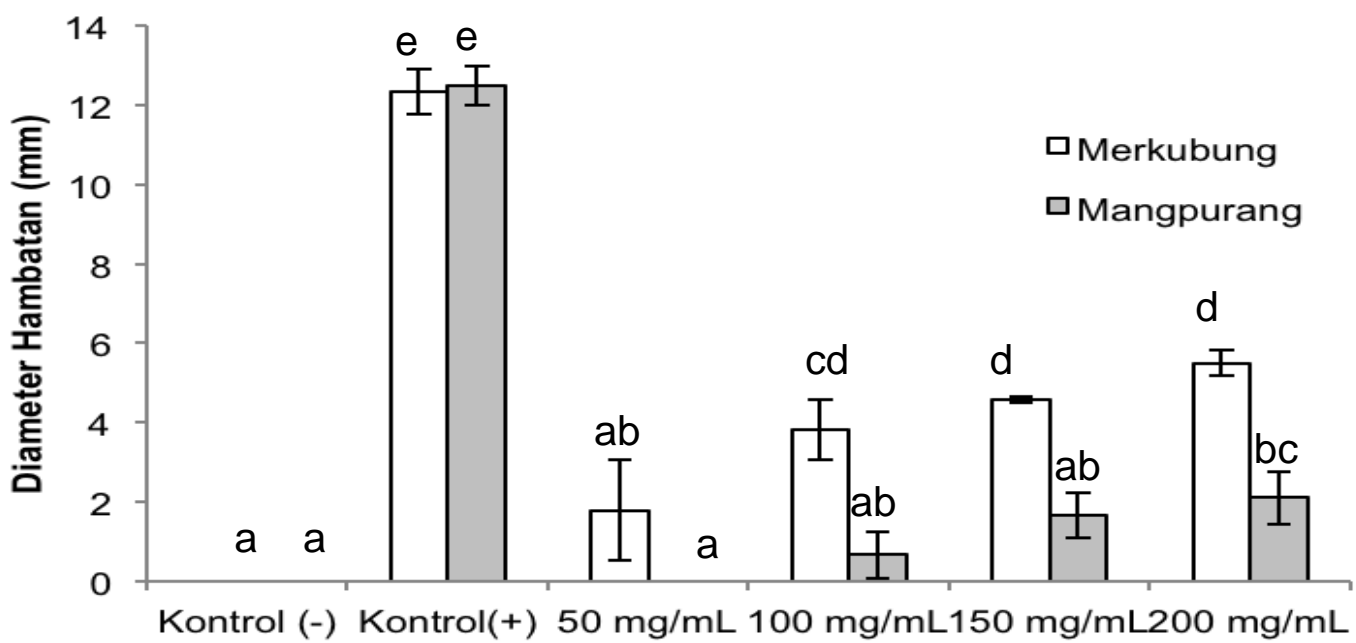

Gambar 2. Grafik rerata \pm SD daya hambat ekstrak etanol kulit batang M. gigantea dan M. triloba terhadap pertumbuhan bakteri E. faecalis

Keterangan: Pengkodean dengan huruf yang sama pada grafik mengindikasikan tidak berbeda nyata pada level kepercayaan $99 \%$.

Pengujian dilakukan dengan 3 kali ulangan dan kedua jenis ekstrak tersebut diujikan pada bakteri $E$. faecalis.

Zona bening yang nampak mengelilingi sekitar kertas cakram menunjukkan bahwa terjadinya daya hambat pertumbuhan bakteri akibat dari efektivitas senyawa yang terkandung pada ekstrak etanol kulit batang $M$. gigantea dan $M$. triloba. Zona bening hasil pengukuran dapat dilihat pada Gambar 2.
Hasil rerata $\pm S D$ daya hambat ekstrak etanol kulit batang $M$. gigantea dan $M$. triloba terhadap pertumbuhan bakteri E. faecalis pada Gambar 2 menunjukkan bahwa pada semua level konsentrasi yang diuji (50, 100, 150 dan $200 \mathrm{mg} / \mathrm{mL}$ ) dapat menghambat pertumbuhan bakteri. Adanya daya hambat pada sampel uji membuktikan bahwa pada konsentrasi tersebut senyawa metabolit sekunder kedua jenis ekstrak sudah mampu dalam 
menghambat pertumbuhan bakteri $E . \quad$ faecalis.
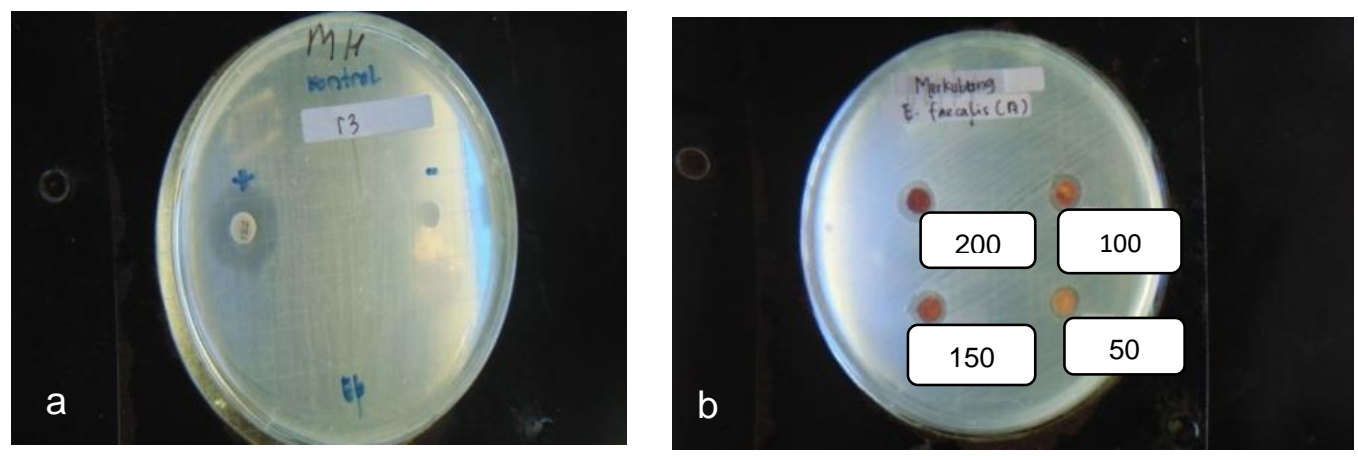

Gambar 3. Respon hambatan aktivitas antibakteri ekstrak etanol kulit batang $M$. gigantea terhadap bakteri $E$. faecalis. a. kontrol positif dan kontrol negatif; b. konsentrasi ekstrak 50,100, 150 dan $200 \mathrm{mg} / \mathrm{mL}$
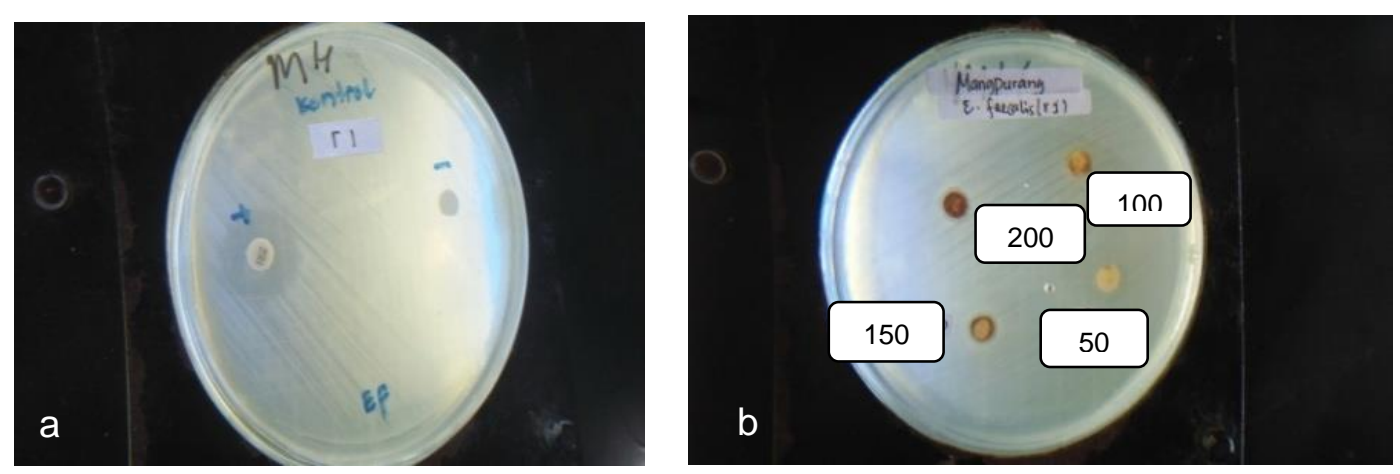

Gambar 4. Respon hambatan aktivitas antibakteri ekstrak etanol kulit batang M. triloba terhadap bakteri E. faecalis a. kontrol positif dan kontrol negatif; b. konsentrasi ekstrak 50, 100, 150 dan $200 \mathrm{mg} / \mathrm{mL}$.

Ekstrak etanol kulit batang $M$. gigantea pada level konsentrasi 50 $\mathrm{mg} / \mathrm{mL}$ daya hambatnya sebesar 3,25 $\mathrm{mm}$, konsentrasi $100 \mathrm{mg} / \mathrm{mL}$ daya hambatnya sebesar 4,62 $\mathrm{mm}$, konsentrasi $150 \mathrm{mg} / \mathrm{mL}$ daya hambatnya sebesar $4,5 \mathrm{~mm}$ dan pada konsentrasi $200 \mathrm{mg} / \mathrm{mL}$ daya hambatnya sebesar $5,25 \mathrm{~mm}$.

Hasil penelitian pada ekstrak etanol kulit batang $M$. triloba daya hambatnya terjadi pada konsentrasi 100, 150 dan $200 \mathrm{mg} / \mathrm{mL}$, sedangkan pada konsentrasi $50 \mathrm{mg} / \mathrm{mL}$ tidak terdapat daya hambat. Hal ini membuktikan bahwa ekstrak etanol kulit batang $M$. triloba belum mampu menghambat pertumbuhan bakteri $E$. faecalis pada level konsentrasi 50 $\mathrm{mg} / \mathrm{mL}$. Ekstrak M. triloba pada level konsentrasi $100 \mathrm{mg} / \mathrm{mL}$ daya hambatnya sebesar $1 \mathrm{~mm}, 150 \mathrm{mg} / \mathrm{mL}$ sebesar $2 \mathrm{~mm}$ dan pada $200 \mathrm{mg} / \mathrm{mL}$ sebesar 2,87 $\mathrm{mm}$.

Pengujian kontrol negatif (etanol 96\%) menunjukkan tidak adanya daya hambat yang terbentuk. Hal ini membuktikan bahwa zona hambat yang terdapat pada media uji merupakan murni hasil dari senyawasenyawa metabolit sekunder pada kedua jenis ekstrak. Sedangkan pada 
kontrol positif (tetracycline) memiliki daya hambat sebesar $12 \mathrm{~mm}$ dan 13 $\mathrm{mm}$.

Hasil penelitian menunjukkan bahwa kedua jenis ekstrak mampu menghambat pertumbuhan bakteri $E$. faecalis, dimana antara perlakuan 200 , 150 dan $100 \mathrm{mg} / \mathrm{mL}$ pada kedua jenis ekstrak dalam menghambat pertumbuhan aktivitas bakteri menunjukkan tidak berbeda nyata, sehingga dapat dikatakan konsentrasi 200, 150 dan $100 \mathrm{mg} / \mathrm{mL}$ memiliki pengaruh yang sama. Namun, konsentrasi $100 \mathrm{mg} / \mathrm{mL}$ merupakan konsentrasi terbaik dari kedua jenis ekstrak pada semua perlakuan dalam menghambat pertumbuhan bakteri $E$. faecalis.

Hasil uji juga membuktikan semakin tinggi level konsentrasi, maka bertambah juga zona hambat yang dihasilkan, meskipun penambahan zona beningnya tidak terlalu besar. Daya hambat yang ditandai dengan adanya zona bening yang mengelilingi kertas cakram dapat dilihat pada Gambar 3 untuk ekstrak $M$. gigantea dan pada Gambar 4 untuk ekstrak $M$. triloba.

Berdasarkan pengelompokan zona hambat pertumbuhan bakteri (Anita et al., 2014), hasil pengujian pada ekstrak etanol kulit batang $M$. gigantea terhadap bakteri $E$. faecalis menunjukkan daya hambat dengan kategori sedang. Pada konsentrasi tertinggi yaitu $200 \mathrm{mg} / \mathrm{mL}$ memiliki daya hambat sebesar $5,25 \mathrm{~mm}$ dan pada konsentrasi 50, 100 dan 150 $\mathrm{mg} / \mathrm{mL}$ tergolong dalam kategori daya hambat lemah, dikarenakan daya hambat yang dimiliki $<5 \mathrm{~mm}$.

Ekstrak M.triloba pada semua konsentrasi daya hambat tergolong dalam kategori lemah dikarenakan pada semua level konsentrasi daya hambat yang diperoleh $<5 \mathrm{~mm}$. Bahkan pada level konsentrasi tertinggi $200 \mathrm{mg} / \mathrm{mL}$, daya hambat hanya sebesar 2,87 $\mathrm{mm}$. Hasil pengujian tersebut menunjukkan bahwa ekstrak etanol kulit batang $M$. gigantea dan $M$. triloba mempunyai senyawa yang mampu menghambat aktivitas antibakteri, meskipun masih tergolong sedang dan lemah. Ini dikuatkan dengan hasil penelitian Charyadie et al., (2014) yang menggunakan bagian daun pada tanaman (alpukat) berupa ekstrak yang diujikan pada bakteri $E$. faecalis untuk melihat respon hambatan, dimana pada konsentrasi $100 \%$ sudah memperoleh daya hambat sebesar $11.82 \mathrm{~mm}$.

Rendahnya aktivitas antibakteri yang ditunjukkan pada penelitian ini diduga karena karateristik bakteri itu sendiri, dimana bakteri gram positif ( $E$. faecalis) memiliki struktur lapisan penyusun seperti dinding sel berupa peptidoglikan yang tebal. Putri et al., (2018) mengemukakan bahwa bakteri dari genus Enterococcus mempunyai kemampuan untuk menghasilkan katalase negatif yang dapat menghambat kerja dari antibiotik.

Hasil penelitian ini membuktikan bahwa kedua jenis ekstrak sudah mampu menghambat pertumbuhan bakteri. Ini sesuai apabila dilihat dari hasil pengujian secara fitokimia pada ekstrak etanol kulit batang $M$. gigantea dan $M$. triloba, dimana senyawa yang teranalisis yaitu senyawa alkaloid, flavonoid, saponin, terpenoid, tanin dan fenolik. Senyawa-senyawa tersebut diduga dapat menghambat aktivitas pertumbuhan bakteri (Suerni 2013; Prihatiningtyas et al., 2018).

Hasil analisis uji fitokimia menunjukkan adanya kandungan alkaloid dalam jumlah yang banyak terutama pada pereaksi Dendrograff. Menurut Muhaimin et al., (2018) senyawa alkaloid mempunyai aktivitas antibakteri yang mampu menghambat bahkan mematikan struktur penyusun dari bakteri. Kemampuan alkaloid 
dalam menganggu kerja dari sistem bakteri erat kaitannya dengan kemampuan senyawa alkaloid berinteraksi dengan DNA, karena interaksi tersebut berdampak pada terhambatnya proses sintesis DNA (Mawan et al., 2018).

Sejalan dengan pernyataan Muhaimin et al., (2018) dan Rismawati et al., (2018) senyawa flavonoid mempunyai aktivitas antibakteri yang mampu menghambat bahkan mematikan struktur penyusun dari bakteri. Aktivitas dari senyawa flavonoid dalam bekerja dengan cara menyerang membran sel yang menyebabkan kerusakan pada membran sel tersebut dan flavonoid juga menghambat sintesis makromolekul sel bakteri. Pernyataan tersebut sama dengan Rahman et al., (2017) yang menyatakan bahwa senyawa flavonoid mempunyai sifat antibakteri yang dapat menghambat pertumbuhan bakteri dengan cara menyerang struktur penyusun bakteri berupa metabolisme energi, sintesis asam nukleat dan fungsi membran sel, yang menyebabkan terganggunya sistem kerja dari bakteri.

Uji fitokimia pada ekstrak etanol kulit batang $M$. gigantea dan $M$. triloba juga mengandung senyawa saponin. Menurut Akinpelu et al., (2014) senyawa saponin memiliki kemampuan dalam menghambat aktivitas dari bakteri. Aktivitas saponin dalam menghambat pertumbuhan bakteri yaitu, melalui mekanisme peningkatan permeabilitas membran sel yang dapat menyebabkan kematian dikarenakan hancurnya membran sel bakteri (Prihatiningtyas et al., 2018).

Mariajancyrani et al., (2013) dan Mawan et al., (2018) mengemukakan bahwa terpenoid mempunyai kemampuan dalam menghambat pertumbuhan bakteri. Adapun mekanisme kerja senyawa terpenoid adalah dengan cara merusak membran sel bakteri. Kerusakan tersebut disebabkan oleh senyawa aktif dari kedua jenis ekstrak yang bereaksi dengan komponen aktif pada membran atau mengencerkan konstituen lipid serta membuat permeabilitas meningkat. Ini dikarenakan terjadinya peningkatan permeabilitas yang menyebabkan mudahnya senyawa aktif pada ekstrak masuk ke dalam sel penyusun bakteri yang nantinya akan menghancurkan membran sel atau mengkoagulasi sitoplasma sehingga sel bakteri tidak dapat berfungsi sebagaimana mestinya (Rahman et al., 2017).

Selain itu, menurut Akiyama et al. (2011) mekanisme kerja tanin sebagai antibakteri dalam membentuk zona hambat melalui perusakan membran sel bakteri. Hal ini terjadi dikarenakan saat proses toksisitas pada senyawa tanin, ada pembentukan ion logam dari tanin yang mempunyai banyak fungsi, diantaranya saat reduksi dari prekursor ribonukleotida DNA terutama bakteri yang tumbuh dan hidup pada kondisi memerlukan oksigen dalam pe-mecahan senyawa glukosa yang menyebabkan terganggunya berbagai fungsi dari bakteri. Hasil pengujian skrining fitokimia juga menunjukkan senyawa fenolik dalam konsentrasi jumlah yang banyak pada kedua jenis ekstrak.

Menurut Prihatiningtyas et al. (2018) mekanisme kerja senyawa fenolik dapat menghambat pertumbuhan aktivitas bakteri dengan cara melakukan oksidasi pada bakteri, dimana sistem kerjanya merusak beberapa bagian seperti dinding sel, substrat pada bakteri dihilangkan dan melumpuhkan kerja enzim. Secara umum senyawa-senyawa metabolit sekunder memiliki mekanisme kerja sebagai antibakteri dengan menyerang struktur penyusun bakteri yang berakibat terhambat, rusak dan 
bahkan mematikan sistem kerja dari bakteri, diantaranya mengganggu kerja enzim, sintesis protein, permeabilitas membran dan merusak dinding sel (Siregar et al., 2012).

\section{KESIMPULAN}

Rendemen ekstrak kulit batang M. gigantea sebesar 9,18\% dengan kadar air serbuk sebesar $9,15 \%$ dan ekstrak kulit batang $M$. triloba sebesar $9,70 \%$ dengan kadar air serbuk sebesar 8,56\%. Proses skrining fitokima memperoleh hasil senyawa aktif diantaranya senyawa alkaloid, terpenoid, tanin, flavonoid, saponin dan fenolik pada kedua jenis ekstrak. Level konsentrasi $100 \mathrm{mg} / \mathrm{mL}$ merupakan konsentrasi terbaik dari kedua jenis ekstrak untuk menghambat pertumbuhan bakteri $E$. faecalis, namun diantara kedua jenis ekstrak tersebut yang terbaik dalam menghambat pertumbuhan $E$. faecalis adalah $M$. gigantea.

\section{REKOMENDASI}

Berdasarkan hasil penelitian ini maka diperlukan penelitian lanjutan guna mengetahui pengaruh ekstrak etanol kulit batang $M$. gigantea dan $M$. triloba terhadap beberapa jenis bakteri lain sehingga kedepannya potensial sebagai agen antibakteri baru. Rekomendasi yang dapat diberikan berdasarkan hasil penelitian ini adalah dalam rangka mendukung terwujudnya desa yang mandiri dalam aspek kesehatan, pemerintah setempat diharapkan dapat memberikan dukungan dan himbauan kepada masyarakat agar dapat melakukan budidaya serta pemeliharaan tanaman dari kedua genus Macaranga ini. Dengan demikian, sumberdaya alam serta pengetahuan lokal masyarakat dalam pengobatan tradisional dapat terjaga.

\section{DAFTAR PUSTAKA}

Akinpelu BA, lgbeneghu OA, Awotunde Al, Iwalewa EO, Oyedapo OO. 2014. Antioxidant and Antibacterial Activities of Saponin Fractions of Erythropheleum suaveolens (Guill And Perri.) Stem Bark Extract. Scientific Research and Essays. 9 (18): 826-833.

Akiyama H, Fuji K, Yamasaki O, Oono T, Iwatsuki K. 2001. Antibacterial action of several tannins against Staphylococcus aureus. Journal of antimicrobial chemotherapy. 48(4): 487-491.

Anita A, Khotimah S, Yanti AH. 2014. Aktivitas Antibakteri Ekstrak Daun Benalu Jambu Air (Dendropthoe petandra L. Miq.) J. Protobiont. 3(2): 268-272.

Amirta $\mathrm{R}$, Angi $\mathrm{EM}$, Ramadhan $\mathrm{R}$, Kusuma IW, Wiati CB dan Haqiqi MT. 2017. Potensi Pemanfaatan Macaranga. Samarinda: Mulawarman University Press.

Apriani AS, Saleh C, Alimuddin 2014. Uji Fitokimia dan Aktivitas Antibakteri Dari Tanaman Merkubung (Macaranga gigantea (Rchb. f. \& Zoll) Mull. Arg.) Dengan Ekstrak Total, Fraksi N-heksana, Etil Asetat dan Etanol Air Terhadap Bakteri Escherichia coli dan Staphylo coccusaureus. J. Kimia Mulawarman. 12(1):3741.

Astarina NWG, Astuti KW, Warditiani NK. 2013. Skrining Fitokimia Ekstrak Metanol Rimpang Bangle (Zingiber purpureum Roxb). J. Farmasi Udayana. 2(4): 1-7. 
Aziz T, Ratih CKN, Fresca A. 2009. Pengaruh Pelarut Heksana dan Etanol, Volume Pelarut, dan Waktu Ekstraksi Terhadap Hasil Ekstraksi Minyak Kopi. J. TeknikKimia. 1(16): 1-8.

Charyadie FL, Adi S dan Sari RP. 2014. Daya Hambat Ekstrak Daun Alpukat (Persea americana, Mill.) Terhadap Pertumbuhan Enterococcus faecali. J. Kedokteran Gigi. 8(1):1907-5987.

Darussalam H. 2016. Uji Sensitivitas Ekstrak Kayu Ulin (Eusideroxylon zwageri) terhadap Pertumbuhan Bakteri Staphylococcus aureus Secara In Vitro. Mahakam Medical Laboratory Technology Journal. 1(2):81-90.

Dasopang ES. 2017. Skrining Fitokimia dan Uji Aktivitas Antibakteri Ekstrak Etanol Daun Sangitan (Sambucus javanica Rainw) Terhadap Pertumbuhan Bakteri Escherichia coli dan Salmonella thypi. J. Biologi Lingkungan, Industri, Kesehatan. 4(1):54-62.

Davis WW dan Stout TR. 1971. Disc Plate Method of Microbiological Antibiotic Assay. J. Of Microbiology. 22(4):659-665.

Departemen Pertanian. 1976. Vademecum Kehutanan Indonesia. Jakarta: Balai Penjelidikan Kehutanan.

Gagpersz V. 2006. Teknis Analisis dalam Penelitian Percobaan. Ed-1. Cetakkan ketiga. Bandung: Penerbit Tarsito.
Hamidi $H$, Setijonegoro FXN, Fujitriartanto, Sa id A, Harioso, Huda, Hardiyanto A, Waluyanto $B$, Lubis ISG, Setiawan D, Mu`arofah AF. 2015. Indeks Desa Membangun. Kementrian Desa, Pembangunan Daerah Tertinggal dan Transmigrasi. Jakarta.

Harbone JB. 1996. Metode Fitokimia, Penuntun Cara Moderen Menganalisis Tumbuhan. Edisi I. Penerjemah: Padmawinata K dan Soediro I. Bantung: ITB.

Mailuhu M, Runtuwene MRJ, Koleangan HSJ. 2017. Skrining Fitokimia dan Aktivitas Antiosidan Ekstrak Metanol Kulit Batang Soyogik (Saurauia bracteosa DC). Chemistry Prog. 10(1): 1-7.

Manuhuwa E. 2007. Kadar Air dan Berat Jenis Pada Posisi Aksial dan Radial Kayu Sukun (Arthocarpus communis, J.R dan G. Frest). Maluku. J. Agroforestri. 2(1):51-54.

Mariani Y, Yusro F, Konishi Y, Taguchi T, Tominaga A. 2016. Regulatory effects of five medicinal plants used by Dayak Uud Danum in West Kalimantan Indonesia on the delayed type hypersensitivity and the inflammation of human colon epithelial cells. Kuroshio Science. 10:59-71.

Mariajancyrani J, Chandramohan G, Saravanan, Elayaraja A. 2013. Isolation and Antibacterial

Activity of Terpenoid from Bougainvillea glabra Choicy Leaves. Asian Journal of Plant Science and Research. 3(3): 70-73. 
Mawan AR, Indriwati SE, Suhadi. 2018. Aktivitas Antibakteri Ekstrak Metanol Buah Syzygium polyanthum terhadap Pertumbuhan Bakteri Escherchia coli. J. Bioeksperimen. 4(1): 64-68.

Muhaimin M, Yusnaidar Y, Amanda $\mathrm{H}$. 2018. Antimalaria Activity of Macaranga Gigantea Leaves Extracts. Journal of The Indonesian Society of Integrated Chemistry. 10(2): 23-32.

Pasil Y, Yuliansanti A. 2014. Daya Antibakteri Daun Sirih Merah (Piper crocatum) terhadap Bakteri Entrocoocus faecalis sebagai Bahan Madikamen Akar dengan Metode Delusi. Insisiva Dental Journal. 3.(1): 88-95.

Putri YW, Putra EP, Utama BI. 2018. Identifikasi Dan Karakteristik Bakteri AsamLaktat Yang Diisolasi Dari Vagina Wanita Usia Subur. J. Kesehatan Andalas. $\quad 7(3): 20-25$.

Prihatiningtyas $\mathrm{W}$, Mariani $\mathrm{Y}$, Oramahi HA, Yusro F, Sisillia L. 2018. Uji Aktivitas Antibakteri

Ekstrak Etanol Kulit Batang Mangga Kweni (Mangifera odorata Griff) Terhadap Escherichia coli ATCC 25922 Dan Staphylococcus aureus ATCC 25923. J. Tengkawang. 8(2):59-74.

Ramadhinta TM, Nahz MYI, Budiarti LY. 2016. Uji Efektivitas Antibakteri Air Perasan Jeruk Nipis (Citrus aurantifolia) sebagai Bahan Irigasi Saluran Akar Alami terhadap

Pertumbuhan Enterococcus faecalis In Vitro. Dentino Jurnal Kedokteran Gigi. I(2):125-126.

Rahmah SH, Suharti, Subandi.2014. Uji Antibakteri dan Daya Inhibisi Ekstrak Kulit Manggis (Gracinia Mangostana L.) Terhadap
Aktivitas Xantin Oksidase yang Diisolasi dari Air Susu Segar Sapi. J. Kimia UM Online.2(2):111.

Rahman FA, Haniastuti T, Utam TW. 2017. Skrining Fitokimia Dan AktivitasAntibakteri Ekstrak Etanol Daun Sirsak (Annona $\begin{array}{lll}\text { muricata L.) Pada } & \end{array}$ Streptococcus mutans ATCC 35668. Majalah Kedokteran Gigi Indonesia. 3(1): 1-7.

Rismawati, Marliana E, Daniel. 2018. Uji Fitokimia Ekstrak Metanol Daun Macaranga Hullettii King Ex Hook.F. J. Atomik. 3(2): 91-94.

Siregar AF. Sabdono A. Pringgenies D. 2012. Potensi antibakteri ekstrak rumput laut terhadap bakteri penyakit kulit Pseudomonas aeruginosa, Staphylococcus epidermidis dan Micrococcus luteus. Journal of marine research. 1(2): 152160.

Sjostrom E. 1981. Wood Chemistry: Fundamentals and Aplications. Academic Press. London. New York.

Sulaeman ES, Karsidi R, Murti B, Kartono DT, Waryana, dan Hartanto R. 2012. Model Pemberdayaan Masyarakat Bidang Kesehatan, Studi Program Desa Siaga. J. Kesehatan Masyarakat Nasional. 7 (4). 186-192.

Suerni E, Alwi M, Guli MM. 2013. Uji Daya Hambat Ekstrak Buah Nanas (Ananas comosus L. Merr.), Salak (Salacca edulis Reinw.) dan Mangga Kweni (Mangifera odorata Griff.) Terhadap Daya Hambat Staphylococcus aureus. J. Biocelebes. 7(1): 35-47. 
Trina, Fitmawati, Sofiyanti N. 2014. Identifikasi Tumbuhan Antidiabetes Berdasarkan Analisis Kuantitatif Asam Tanat. JOM FMIPA. 1(2): 409-416.

Wasito H. 2011. Obat Tradisional Kekayaan Indonesia. Edisi ke-1. Cetakan pertama. Yogyakarta: Graha IImu.Wila H, Yusro F, Mariani Y. 2018. Skrining Fitokimia Dan Aktivitas Antibakteri Ekstrak Kulit Batang (Eusideroxylon zwageri) Terhadap Escherichia coli Dan Salmonella typhi. J. Tengkawang. 8.(1): 38 - 49.

Widyastuti N. 2010. Pengukuran Aktivitas Antioksidan dengan Metode Cuprac, Dpph, dan Frap Serta Korelasinya dengan Fenol dan Flavonoid pada Enam Tanaman. Fakultas Matematika Dan IImu Pengetahuan Alam. Institut Pertanian Bogor. Bogor.Yusro F, Ohtani K,

Kubota S. 2016. Inhibition of $\alpha$ Glucosidase by Methanol Extracts from Wood Bark of Anacardiaceae, Fabaceae, Malvaceae and Phyllanthaceae Plants Family in West Kalimantan, Indonesia. Kuroshio Sci nce. 9(2): 108-12 